UDC 691.3:678.5.03

UDC 662.741.332.2

\author{
Zh.K. Kairbekov', V.S. Yemelyanova ${ }^{2}$, B.B. Baizhomartov ${ }^{2}$ \\ ${ }^{1}$ Al-Farabi Kazakh National University, Kazakhstan, Almaty \\ ${ }^{2}$ BSE Scientific Research Institute of New Chemical Technologies and Materials of the RSE \\ Al-Farabi Kazakh National University, Kazakhstan, Almaty \\ *E-mail: niinhtm@mail.ru
}

\title{
Thermocatalytical processing of coal and shales
}

\begin{abstract}
The article investigates the questions of thermocatalytical conversion of organic mass of coal (OMC), it is shown that in the absence of a catalyst process is carried out by a radical process. Accumulated data on the properties for radicals of different structure and therefore different reaction capacity enables us to understand and interpret the conversion of OMC. Thermal conversion of OMC regarded as a kind of depolymerization, accompanied by decomposition of the functional groups with the formation of radicals, competing for hydrogen atom. Catalyst can change the direction and conditions of the process. Modern catalysts can reduce the process pressure up to $50 \mathrm{~atm}$., with a high degree of coal conversion. We consider examples of simultaneous conversion of coal and shale, shale and masut, shale and tar.
\end{abstract}

Keywords: shale, coal, catalyst, thermocatalytical processing, destruction, liquid products.

\section{Introduction}

All current used or developed processes for the coal processing - burning, coking, semi-coking, gasification, liquefaction, high temperature oxidation inevitably begin with thermal destruction of organic mass of coal (OMC). Therefore, the most important aspect of chemical properties of OMC is to evaluate the structure of OMC sites with the weakest bends. Obviously, with their break should begin any conversion of OMC, the mechanism and the result of which will depend on what the radicals and what properties in this manner.

Predict which bond in OMC will be the least durable, based on the idea that typically $\mathrm{O}-\mathrm{C}$ bond is less strong than the $\mathrm{C}-\mathrm{C}$ bond, and the latter is weaker than the $\mathrm{C}-\mathrm{H}$ bond, is clearly not enough, as the chemical structure OMC, as shown above, is complex and respect it will be strengthened or weakened the influence of the functional groups and conjugations. Based on the general theoretical principles, we must assume that the breaks will go through the «bridge» and the $\alpha$-bond in a «bridge», reinforced by $\sigma-\pi$; or $p-\pi$ conjugation, will be stronger than the links in the middle of the «bridge».
However, the most reliable information gives direct experiments with substances that simulate these «bridges». However, be aware that this information is too approximate.

Experiments with models mainly reflect the influence of chemical structure, but of course, can not reflect the influence of intermolecular interactions in the $\mathrm{OMC}$ and the possible catalytic effect of inorganic (metal ions). In some cases in detail studied the effect of inorganic compounds as catalysts (see below). Thus, data on the thermolysis of [1] simple compounds like $\mathrm{C}_{6} \mathrm{H}_{5}-\mathrm{X}-\mathrm{C}_{6} \mathrm{H}_{5}$ give an idea of the relative strength of aliphatic, heterocyclic ether and «bridges» (Table 1).

Data [1] shows that the polymethylene «bridges» are stronger than oxygen-methylene and imine-methylene «bridges». But compared to the same two-and three-tier «bridges» gives different results: the strength of a polymethylene chain elongation decreases, and for oxygen-methylene grows. This apparent contradiction is explained by the fact that should be taken into account not only the strength of the bond, but the mechanism of the chain radical reactions, which can occur either energetically favorable formation of radicals, either energetically unfavorable. 
Table 1 - The comparative strength of the simplest «bridges» in compounds such as $\mathrm{C}_{6} \mathrm{H}_{5}-\mathrm{X}-\mathrm{C}_{6} \mathrm{H}_{5}$ during termollize* [1]

\begin{tabular}{|c|c|c|c|c|}
\hline Bridge (X) & Formula & $\mathbf{T},{ }^{\circ} \mathbf{C}$ & $\begin{array}{c}\text { Time, } \\
\text { min }\end{array}$ & $\begin{array}{c}\text { Degree of decomposi- } \\
\text { tion, } \%\end{array}$ \\
\hline$-\mathbf{C H}_{2}-\mathbf{C H}_{2}-$ & $\mathbf{C}_{6} \mathbf{H}_{5}-\mathbf{C H}_{2}-\mathbf{C H}_{2}-\mathbf{C}_{6} \mathbf{H}_{5}$ & $\mathbf{4 0 0}$ & $\mathbf{2 4 0}$ & $\mathbf{8}$ \\
\hline$-\left(\mathbf{C H}_{2}\right)_{3}-$ & $\mathbf{C}_{6} \mathbf{H}_{5}-\mathbf{C H}_{2}-\mathbf{C H}_{2}-\mathbf{C H}_{2}-\mathbf{C}_{6} \mathbf{H}_{5}$ & $\mathbf{4 0 0}$ & $\mathbf{3 0}$ & $\mathbf{2 5}$ \\
\hline$-\mathbf{C H}_{2}-\mathbf{O}-$ & $\mathbf{C}_{6} \mathbf{H}_{5}-\mathbf{C H}_{2}-\mathbf{O}-\mathbf{C}_{6} \mathbf{H}_{5}$ & $\mathbf{3 5 0}$ & $\mathbf{1 0}$ & $\mathbf{3 3}$ \\
\hline$-\mathbf{C H}_{2}-\mathbf{O}-\mathbf{C H}_{2}-$ & $\mathbf{C}_{6} \mathbf{H}_{5}-\mathbf{C H}_{2}-\mathbf{O}-\mathbf{C H}_{2}-\mathbf{C}_{6} \mathbf{H}_{5}$ & $\mathbf{4 0 0}$ & $\mathbf{1 0}$ & $\mathbf{2 2}$ \\
\hline$-\mathrm{CH}_{2}-\mathbf{N H}-\mathrm{CH}_{2}-$ & $\mathbf{C}_{6} \mathbf{H}_{5}-\mathbf{C H}_{2}-\mathbf{N H}-\mathrm{CH}_{2}-\mathbf{C}_{6} \mathbf{H}_{5}$ & $\mathbf{3 5 0}$ & $\mathbf{1 0}$ & $\mathbf{6 0}$ \\
\hline$-\mathbf{C H}_{2}-\mathbf{N H}-$ & $\mathbf{C}_{6} \mathbf{H}_{5}-\mathbf{C H}-\mathbf{N H}-\mathbf{C}_{6} \mathbf{H}_{5}$ & $\mathbf{4 0 0}$ & $\mathbf{2 0}$ & $\mathbf{1 4}$ \\
\hline
\end{tabular}

Accumulated data on the properties of radicals of different structure and therefore different reactivity enables us to understand and interpret the conversion of OMC. From this perspective, the thermal conversion of OMC considered as a kind of depolymerization, accompanied by decomposition of the functional groups with the formation of products that compete with each other for a hydrogen atom. Obviously, the rate of formation of pyrolysis products - gas, liquid products (resins), carbon residue - will be determined by the nature of the «bridging» relationships. Since the latter depends on the degree of metamorphism, it follows that the most rapid transformation to wait for a relatively young coal, from brown to sub-bituminous and bituminous. A satisfactory agreement with the experimental results given by calculation of the output of the pyrolysis products based on the assumption that the structural elements are a group of coal $-\mathrm{COOH},-\mathrm{OH}$, COOR, nitrogen-containing fragments, aliphatic carbon, hydro-and non-volatile compounds (high condensate) part. Process begins with the removal of the $-\mathrm{COOH}$ and $-\mathrm{COOR}$ groups, then goes into OMC fusible state (mezoplast), which are radical reactions. This process is illustrated in [2] for a young coal circuit shown in Figure. 1.
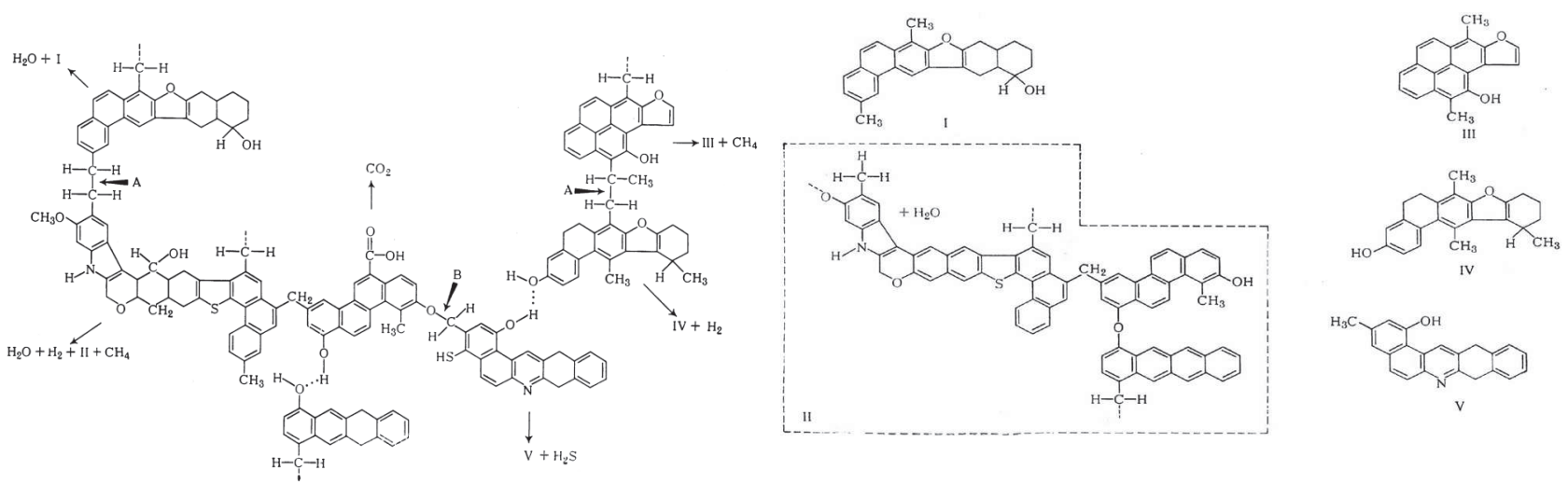

Figure 1 - Scheme of young coal pyrolysis [3]

In the circuit shown the least strong «bridge» connection, carbon dioxide, water, methane and hydrogen formation, with an appropriate flavoring liquid and solid products.

Shards of OMC (on the site diagram breaks are indicated by arrows), if they are not stabilized, condense and form highly aromatic coke. In the presence of hydrogen donors fragments radicals stabilized in liquid products. This is the main difference between thermal chemical processes from the processes of liquefaction, i.e. hydrogenation.
But in the process of hydrogenation, as we know, there is always a danger of condensation reactions (seals) [3].

In light of these features of the chemical structure of the formation of condensation products of OMC will be the case when the radicals formed during the initial collapse, will take up hydrogen in the most OMC. This view was expressed in 1967, it is now almost universally recognized. As mentioned in [4] for a double illustrated diagram: 


$$
\begin{aligned}
& \mathrm{M} \rightarrow 2 \mathrm{R} \bullet \\
& \mathrm{R} \bullet+D \rightarrow \mathrm{R}^{\prime} \mathrm{H}+D^{-} \\
& \mathrm{R} \bullet+D \rightarrow \mathrm{R}^{\prime} \mathrm{H}+D^{2-}\left(-\mathrm{H}_{2}\right) \\
& \mathrm{R} \bullet \mathrm{M} \rightarrow \mathrm{R}^{\prime} \mathrm{H}+\mathrm{M}^{-} \\
& \mathrm{R} \bullet+\mathrm{M}^{-} \rightarrow \mathrm{R}^{\prime} \mathrm{H}+\mathrm{M}^{2-}\left(-\mathrm{H}_{2}\right)
\end{aligned}
$$

where M - coal «molecule»; D - donor; H hydrogen; sign - means the removal of a single hydrogen atom; the symbol $-\mathrm{H}_{2}$ - the removal of two atoms, i.e., dehydrogenation and aromatization.

Obviously, for the successful liquefaction of OMC it is needed to accelerate the second and third reactions, balance them with the first, and prevent fourth and fifth. After that we assume that since «bridges» may vary in the strength of ties in a wide range of coal liquefaction is difficult to describe a kinetic equation. Indeed, the best result was obtained in the separation of OMC in the fast and slow forming parts,

$$
\mathrm{R}_{\text {(conversion) }}=\gamma C e^{-\mathrm{k} 1 \mathrm{t}}+(1-\gamma) C e^{-\mathrm{k} 2 \mathrm{t}}
$$

where $\gamma$ - the proportion of reactive $\mathrm{C}$ - share convertible OMC (in the following research 91\%); $\mathrm{k}_{1}$ and $\mathrm{k}_{2}$, respectively, 3.02 and 0.116 at $\mathrm{t}=386^{\circ} \mathrm{C}$, min- 1

A significant difference between the liquefaction rate of $\mathrm{OMC}$ in the initial and final period of the process, defined by non-uniform structure of OMC (see above), it was noted repeatedly, proposed to use this law to intensify the process of liquefaction, i.e., if only limited liquefaction responsive of weapons of mass destruction can be increased several times volume temporary liquid yield.

The stabilization of the radicals formed in the thermolysis of OMC is therefore a key aspect of ensuring coal liquefaction during hydrogenation. This stabilization may be performed as a specially designed liquid hydrogen donor and hydrogen gas.

Probably both sources are important. On the one hand, based on the above data on the chemical properties of the $\mathrm{OMC}$ to be expected that the radicals formed by thermolysis of primary, more stable and less reactive, resulting in stabilization of hydrogen will be hindered. So, in the early stages of liquefaction is very important function of the donor solvent. Indeed, in all developed new processes liquefaction necessarily apply paste formers having a donor function and great attention are paid to the optimization of the adjustable pasta. On the other hand, have long known that coal liquefaction occurs more intense the higher the applied pressure of hydrogen. Therefore, the stabilization of radicals with molecular hydrogen is also very important.
Controlled reactions can break certain bonds by selectively introducing metal catalysts in the functional groups of the coal substance. For example, the temperature gap aliphatic bond connecting two aromatic moieties is reduced if the divalent cation replaces the protons of two adjacent phenol groups:

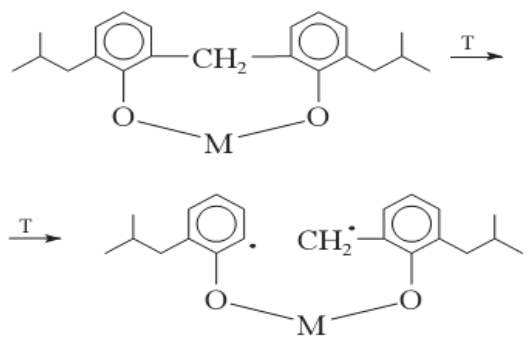

Gained international experience in the development of catalysts for the hydrogenolysis of coal shows that the best catalysts are substances with more or less acidic. Good catalyst must meet the following requirements:

- Stabilize the low molecular weight fragments formed without secondary polymerization;

- Should not be deactivated by sulfur, which is always present in coals;

- Promote the removal of nitrogen and sulfur from coal liquefaction products;

- Should be inert to the mineral coal and metals present in the ash.

These requirements satisfy the oxides of molybdenum, iron, tungsten and vanadium. It should be noted that the cost of the last two elements far exceeds the cost of molybdenum and iron.

However, despite such a narrow range of recommended contacts in published papers and patents on coal hydrogenation catalysts used in virtually all elements of the periodic table. The use of soluble metal salts $\left(\mathrm{Fe}^{+2}, \mathrm{Fe}^{+3}, \mathrm{Sn}^{+2}, \mathrm{Zn}^{+2}\right.$, $\mathrm{Ni}^{+2}, \mathrm{Mo}^{+6, \text { etc.) }}$ as catalysts for the hydrogenation of coal evenly apply the active metal by adsorption on the surface of coal. This method achieves the most favorable conditions for the hydrogenation of coal, with the conversion of $\mathrm{OMC}$ is from 60 to $80 \mathrm{wt}$. $\%$.

However, the use of relatively expensive «clean» metal salts as catalysts disposable significant impact on the cost of coal hydrogenation technology. In this regard, research scientists, especially in recent years, designed to search for active catalysts based on iron ore or waste, electroplating and metallurgical enterprises. A brief description of these developments, mainly in the period 1986-2007 y. presented in [6]. 
Table 2 - Coal hydrogenation catalysts based on iron and its oxides and hydroxides [6].

\begin{tabular}{|c|c|c|c|c|}
\hline \multirow[b]{2}{*}{ 总 } & \multicolumn{4}{|c|}{ Hydrogenation conditions } \\
\hline & $\mathrm{T}, \mathrm{K}$ & $\begin{array}{l}\mathrm{P}_{\mathrm{H}} \\
\mathrm{MPa}\end{array}$ & Catalyst & $\begin{array}{l}\text { Solvent pasta formation, reaction time and other } \\
\text { process parameters }\end{array}$ \\
\hline & 683 & $\begin{array}{l}6.0 \text { (ini- } \\
\text { tial) }\end{array}$ & Waste containing Fe & Tetralin, $\mathrm{t}=30 \mathrm{~min}$ \\
\hline : & 723 & 11.0 & $\begin{array}{l}\text { Fe-ore }\left(\mathrm{Fe}_{2} \mathrm{O}_{3}-71 \%\right) \text {, (red mud }(7.2 \%), \\
\text { fly ash }(\mathrm{Fe}>80 \%) \text {, magnesite }(\mathrm{Fe}-30- \\
31 \%, \mathrm{FeO}-10-11 \%) \text {, as well as } \mathrm{K}_{1} \\
\ll 3673 »(\%): 10-14 \mathrm{MO}+2.0 \mathrm{Co}+5 \mathrm{Ni} / \mathrm{g}- \\
\mathrm{A}_{2} \mathrm{O}_{3} \text { and «4812» }(\%): 15 \mathrm{Mo}+5 \mathrm{NiO}+ \\
8 \mathrm{SiO}_{2}, \text { Bayer's weight }\left(\mathrm{Fe}_{2} \mathrm{O}_{3}-34 \%\right) \text {. }\end{array}$ & $\begin{array}{l}\text { Solution: medium and heavy oil, a mixture of oils, } \\
\text { anthracite. Oil with } \mathrm{H} / \mathrm{C}-1.271-0.799 \text {. The most } \\
\text { active is mass Bayer. Conversion degree of coal } \\
84-87 \% \text {. Oil yield }-43.1 \% \text {. With the introduction of } \\
0.6 \% \mathrm{Na}_{2} \mathrm{~S}-\text { oil yield up to } 57 \% \text {. }\end{array}$ \\
\hline \multirow{3}{*}{ 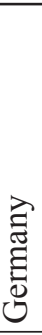 } & $\begin{array}{l}693- \\
753\end{array}$ & $20-30$ & $\begin{array}{l}\text { Red mud from } \mathrm{Al} \text { production. } 5-85 \% \\
\text { oxides, hydroxides or oxyhydroxides } \\
\text { Fe+Ni, Mn, Cr, Mo, W, Ti, Ag, Zn etc.) }\end{array}$ & $\begin{array}{l}\text { Semi coke average oil. C:Solvent:Catalyst }=1: 2: 0,15 \text {, } \\
\mathrm{t}=60 \text { min. Oil yield with a b.p. }>598=75 \% .\end{array}$ \\
\hline & 693 & 25.0 & $\begin{array}{l}\text { Calcine pyrite }(\%)(\mathrm{Fe}-42.8 ; \mathrm{Na}-2.5 \\
\mathrm{Al}-4.6 ; \mathrm{Si}-8.1 ; \mathrm{S}-1.3 ; \mathrm{K}-2.7 ; \mathrm{Ca}- \\
0.3 ; \mathrm{Ti}-0.1 ; \mathrm{Zn}-0.3)\end{array}$ & $\begin{array}{l}\text { Semi coke average oil. C:Solvent:Catalyst }=1: 2: 0.13 \text {, } \\
\mathrm{t}=60 \text { min. Oil yield up to } 34 \% .\end{array}$ \\
\hline & $\begin{array}{l}688- \\
693 \\
\end{array}$ & 27.5 & Fe compounds & $\begin{array}{l}\text { Average oil. C:Solvent }=1: 1 . \text { Catalyst }=0.5-1: 0 \% . t \\
=60 \mathrm{~min} . \text { Oil yield up to } 28-34 \% .\end{array}$ \\
\hline \multirow[t]{2}{*}{$\begin{array}{l}\ll \\
ٌ \\
ٍ\end{array}$} & 693 & $\begin{array}{l}10.0 \\
\text { (initial) }\end{array}$ & $\begin{array}{l}\text { Fe ore with Fe content from } 10 \text { to } 50 \% \\
\left(\text { прис. } \mathrm{MgO}, \mathrm{CaO}, \mathrm{K}_{2} \mathrm{O}, \mathrm{Na}_{2} \mathrm{O}\right) . \mathrm{S}_{\text {уд }}= \\
77.2 \mathrm{M}^{2} / \Gamma . \text { The catalyst was pre-treated in } \\
\text { a reducing atmosphere }\left(\mathrm{H}_{2}, \mathrm{CO}\right)\end{array}$ & $\begin{array}{l}\text { Creosole oil. C:Solvent }=1: 1.5 . \mathrm{t}=60 \mathrm{~min} \text {. The } \\
\text { degree of conversion of coal } 95.8 \% \text {, gas output } 8.4 \% \text {, } \\
\text { Liquid products } 75.4 \% \text {. }\end{array}$ \\
\hline & 753 & $7.0-14.0$ & $\mathrm{Fe}$ or $\mathrm{Fe}$ ore & Creosole oil, Liquid products output up to $80 \%$ \\
\hline \multirow[b]{3}{*}{ 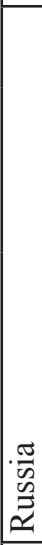 } & 693 & 10.0 & Compounds of Fe, Mo, Co, $\mathrm{Ni}$ & $\begin{array}{l}\text { Increasing the concentration of } \mathrm{CH}_{3} \mathrm{OH}>10-20 \% \\
\text { reduces the activity of the catalyst. }\end{array}$ \\
\hline & 693 & $6.0-10.0$ & $\begin{array}{l}\text { Concentrate flotation tailings electromag- } \\
\text { netic separation Fe-ore mixed with } \mathrm{S} \\
(2.0-5.0 \%) \text { by weight of } \mathrm{C} \text {. }\end{array}$ & $\begin{array}{l}\text { Coal previously subjected to mechanochemical in } \\
\text { aqueous } \mathrm{NaOH}(0.1-0.5 \mathrm{~m} / 1) \text { centrifugal acceleration } \\
\text { of } 600-1000 \mathrm{~m} \rrbracket \mathrm{s}^{2} . \text { Increased carbon conversion and } \\
\text { liquid products yield. }\end{array}$ \\
\hline & 703 & $\begin{array}{l}6.0 \text { (in)- } \\
11.0- \\
12.0 \\
\text { (operat- } \\
\text { ing) }\end{array}$ & $\begin{array}{l}\text { Waste polymetallic and Fe-ore for steel } \\
\text { making. The catalyst was activated, } \\
\text { mechanochemical treatment with the ad- } \\
\text { dition of S, introduced in coal oil pasta in } \\
\text { the form of powder and slurry. }\end{array}$ & $\begin{array}{l}\text { Pastaformational: 1) } 30 \% \text { гидр.фр. } 573-673 \text { К }+ \\
70 \% \text { fr. }>673 \text { К. 2) fr. }>623 \text { К } 3 \text { ) }>623 \text { K (product of } \\
\text { cracking). Coal of Kansk-Achinsk reservoir, Boro- } \\
\text { dino field: conversion degree without catalyst } 28 \% \text {, } \\
\text { catalyst (powder) - } 60-80 \% \text {, suspension }-85-95 \% \text {. } \\
\text { Catalyst - } 1 \% \text { of the weight of the sample Rudny } \\
+0.8 \% \text { of the weight S. }\end{array}$ \\
\hline \multirow[b]{3}{*}{ 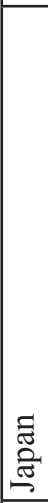 } & 693 & 20.3 & $\begin{array}{l}\text { Enriched ore }(\%): \mathrm{Fe}-65.1 ; \mathrm{FeO}-7.2 ; \\
\mathrm{SiO}_{2}-5.4 ; \mathrm{A}_{2} \mathrm{O}_{3}-0.5 ; \mathrm{CaO}-0.4, \mathrm{MgO} \\
-0.3 ; \mathrm{W}-0.7, \mathrm{~S}=0.01 \% \text { of the weight } \\
\text { of coal }\end{array}$ & $\begin{array}{l}\text { Coal «Taiheiyo» (Japan). Concentration of coal in } \\
\text { the pasta } 30 \%, \mathrm{t}=0-10 \mathrm{~min} \text {. Oil yield } 75 \% \text { for the } \\
\text { organic mass of coal. }\end{array}$ \\
\hline & $\begin{array}{l}673- \\
723\end{array}$ & $\begin{array}{l}25.0- \\
30.0\end{array}$ & $\begin{array}{l}\text { Chemically treated austenitic and ferritic } \\
\text { steel. }\end{array}$ & $\begin{array}{l}\text { H-donor, } \mathrm{t}=15-60 \text { min. Liquid yield increases } \\
\text { from } 54 \text { to } 79 \% \text {. The Catalyst activity compared to } \\
\mathrm{Ni}+\mathrm{Mo} / \text { alumina. }\end{array}$ \\
\hline & 693 & $\begin{array}{l}10.0- \\
15.0\end{array}$ & $\begin{array}{l}\text { Red or activated sludge dissolved in } \mathrm{HCl} \\
\text { and reprecipitation } \mathrm{NH}_{4} \mathrm{OH}\end{array}$ & $\begin{array}{l}\text { Solvent }+\mathrm{C} \text { high and low stages of metamorphism, } \\
\text { modified compounds: naphthalene, phenanthrene, py- } \\
\text { rene. Activation or a significant increase in the hydroge- } \\
\text { nolysis of model compounds and oil yield. The yield of } \\
\text { liquid products like industrial catalysts Ni-Mo-S. }\end{array}$ \\
\hline 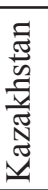 & $\begin{array}{l}673- \\
693\end{array}$ & $\begin{array}{l}\text { to } 5.0 \\
\text { (initial) }\end{array}$ & Natural bauxite containing $\mathrm{Fe}_{2} \mathrm{O}_{3}$ & $\begin{array}{l}\text { In the process of hydrogenation catalyst, reacts with } \\
\text { elemental sulfur to form fine pyrrhotite }\end{array}$ \\
\hline
\end{tabular}


As follows from the results shown in Table 2, the most intense development of technologies of coal hydrogenation using iron-containing wastes for the past 20 years, conducted in Japan, England, Russia. Similar studies are also being conducted in Kazakhstan. Conventional solvents in the laboratory are tetralin, naphthalene, methylnaphthalene, phenanthrene, boiling fractions $(>623 \mathrm{~K})$ of hydrocracking, masut. The degree of conversion (DC) of the organic mass of coal is from $80-87$ to $97 \%$, the yield of oil is from $28-34$ to $75 \%$. Along with liquid products (LP) for the hydrogenation of coal gases by up to $10 \%$ are produced.

It should be noted that the pre-treatment of the catalyst in a reducing atmosphere $\left(\mathrm{H}_{2}, \mathrm{CO}\right)$ or $\mathrm{H}_{2} \mathrm{~S}$ conversion of coal increases. Also mechanochemical activation of iron catalyst and additive $\mathrm{S}$ of 0.01 to $10 \%$ has a positive effect. The hydrogenation is carried out in most of the works in an atmosphere of $\mathrm{N}_{2}$ and Ar atmosphere or $\mathrm{N}_{2}$. It is assumed that in an inert atmosphere of hydrogen donors are solvents (tetralin, boiling fractions of petroleum, etc.). It was also found that the dispersion of the catalyst has a greater impact on the yield of LP than the dispersion of coal. Recently, researchers have paid much attention to the study of the processes of simultaneous catalytic thermal processing of oil shale and lignite.

It is most significant for Kenderlyk, Mamyt and Shubarkol deposits, where both brown coals and shales are present. Studies have shown that organic and mineral part of oil shale have an activating effect on the thermochemical conversion of brown coal, heavy residual oil and liquid waste of some of high oil and chemical industries. Apparently, the explanation of the activating effect of oil shale is: formed in the temperature range $390-440^{\circ} \mathrm{C}$ liquid products liquefying shale contain significant amounts of tetrahydro derivatives condensed aromatic hydrocarbons, oxygen and nitrogen compounds, and alicyclic alcohols, which have (in this temperature range) a hydrogen properties. By their hydrogen donor activity, these compounds are similar to tetralin and in some reactions surpass it in terms of reactivity. This is confirmed by data showing that in the temperature range $390-440^{\circ} \mathrm{C}$ in the cracking of hydrocarbons in the presence of shale active reactions of hydrogenation of unsaturated hydrocarbons ( $\alpha$-methylstyrene aliphatic alkenes), recovery of oxygen compounds (acetophenone to ethylbenzene), suppressed the dimerization reaction ( $\alpha$-methylstyrene in its dimer) condensation to coke shaped products and accelerated degradation of the carbon-carbon bond (conversion of 2-phenyl-2-gidroksifenilpropana to phenol and isopropylbenzene).

The mineral part of oil shale containing aluminum silicates, iron oxides and other catalytically active forms of metals, in turn, activates the flow of cracking reactions.

The presence of such a complexproperties of oil shale is a change not only the reactivity of the components of hydrocarbons, but also the size of supramolecular structures that are an integral part of such a dispersed system, and the preparation of raw mix, with its heat and hydrogenation. As the results of research, the catalytic properties of oil shale can be carried out in optimum conditions, the process of hydrogenolysis of the organic mass of coal and heavy oil feedstock with a high degree of conversion to liquid distillate products without intensive coke-and pellet formation [6]. Results of joint catalytic thermal processing of brown coal and shale deposits Kenderlyk summarized in Table 3.

Table 3 - Thermochemical processing of Kenderlyk coal and Kenderlyk shale and coal mixtures [6]

\begin{tabular}{|l|c|c|}
\hline Process parameters & Coal & Coal+shale \\
\hline Process conditions & $1: 1.3$ & $(0.6+0.4): 1.3$ \\
\hline $\begin{array}{l}\text { Coal:pastaformation } \\
\text { (shale+coal):pastaformation }\end{array}$ & & $1: 0.9$ \\
\hline OMS : OMC & 420 & 420 \\
\hline Temperature, ${ }^{\circ} \mathrm{C}$ & 5.0 & 5.0 \\
\hline Pressure, $\mathrm{MPa}$ & 15 & 30 \\
\hline Duration, min & \multicolumn{2}{|l|}{} \\
\hline The yield of products, \% & 11.8 & 4.4 \\
\hline Gas & \multicolumn{2}{|l|}{} \\
\hline
\end{tabular}


Continuation of the table 3

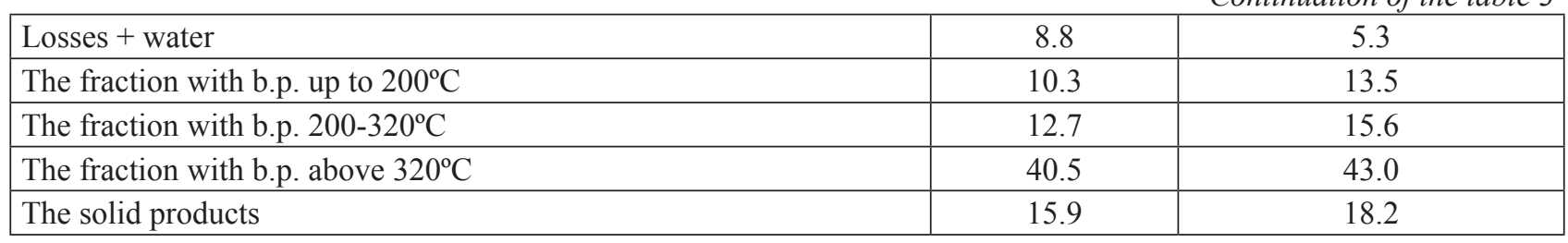

As the results of research, the catalytic properties of oil shale can be carried out in optimum conditions, the process of coal hydrogenolysis of organic matter with a high degree of conversion to liquid distillate products without coking. The conversion of organic matter mixture of shale and coal and oil shale are much higher than the coals. Solid residue with boiling temperature above $320^{\circ} \mathrm{C}$ was tested as an organic binder for road construction. Bitumen based products processing the mixture of shale and lignite of Kendyrlyk deposits satisfy the requirements of GOST 22245-76 for petroleum bitumen.

The disadvantage of the developed process is the lack of thermal dissolution paste formation recovered as a result of that most subjected to hydrogenolysis to give the final products. To reduce this gap has developed a number of techniques of process intensification, which provide not only closed regenerated paste formation process, but may become the basis for creating new areas of catalytic thermal processing of oil shale. This forward direction can be divided into two groups, divided according to the number of input into the process of shale.

Following research [6] shows the conditions and results of the four cycles of the process of thermal dissolution of Baltic shale, in which deficit of the pate forming agent after the previous cycle is covered by the introduction of the oil sludge as an additional component for paste formation.

The results showed that the implementation process cycle IV, which along with the regenerated paste forming agent in the amount of $105 \%$ (based on the slate) introduced $25 \%$ tar, allows an organic binder in a closed process (by paste forming agent) with sufficiently high yield (102.0\%). In addition, a significant amount of gas $(6.7 \%)$ and the gasoline fraction, bp. up to $200^{\circ} \mathrm{C}(14.0 \%)$. Output of gas and petrol per tar is $82.8 \%$.

When introduced into the process of oil sludge at $50 \%$ material balance is fully guaranteed by the formed pasta. In this form gasoline fraction and diesel fraction (bp. $200-335^{\circ} \mathrm{C}$ ) in an amount of $53.6 \%$, almost equal to the volume of $\operatorname{tar}(50 \%)$ being pro- cessed, i.e., when a tar processing introduced almost completely converted to motor spirits.

When introduced into the process even more tar 93.0\% Education gasoline and diesel fractions adds up to $92.4 \%$, i.e. tar also almost completely converted into motor spirits.

In addition to oil sludge as an optional component for paste formation, oil processing waste (phenol, pyrolysis resin cracking residues, sludge) which are not in the currently widespread use, waste oils, shale and coal semicoking fuss can be used. In this case, along with binders, can be produced chemical products (phenol, pyridine, and individual aromatic hydrocarbons), the raw material for the production of carbon black, pitch, electrode coke, etc.

The proposed version of the process technology of thermal dissolution of oil shale in the environment of paste forming agent and tar cycling can get along with organic binders for road construction raw gasoline and diesel fractions, which after appropriate hydro cleaning can be used as motor fuel.

The study of thermal decomposition of oil sludge in the presence of oil shale has allowed for the first time to develop a process of their joint thermo cracking, carried out at $400-440^{\circ} \mathrm{C}, 3-10 \mathrm{MPa}$, in an inert atmosphere or a hydrogen atmosphere at a flow rate $2.1 \mathrm{~h}^{-1}$. This technology is the basis of the second direction of processing of oil shale with the introduction of them into the process in the amount of 8-35 mass \%. It provides reception components of motor, energy fuels and chemical raw materials. This process is also involvement $\neg$ repent heavy oil and residual oil.

By thermal cracking of crude oil from shales occur at different rates thermolysis reaction and condensation. Intensification of chemical transformation is at the stage of raw materials, through the use of methods of changing the degree of polydisperse and the kinetic stability of the reaction system.

Thermal cracking technology mixture of oil shale and tar includes the following stages:

- mixing tar (heavy oil), and in the case of thermal hydrocracking and recycle tar (bp. above $370^{\circ} \mathrm{C}$ ) with crushed oil shales with a paste; 
- thermal cracking and hydrocracking of thermal paste in the reactor floor;

- separation of the solids from the process fluid by centrifugation or vacuum distillation;

- ashless distillation of liquids thermal cracking or thermal hydrocracking.

During thermal hydrocracking of tar mixed with recycled agents (ratio 1:0.2-0.4) and the Baltic shale $(15 \%)$ at a pressure of $10 \mathrm{MPa}$ and a temperature of $425^{\circ} \mathrm{C}$ and a profound transformation of heavy crude oil in the gasoline fraction, bp. up to $200^{\circ} \mathrm{C}$ and diesel fraction, bp. $200-370^{\circ} \mathrm{C}$ - the total yield of $90 \%$ and above.

The proposed process has the following important advantages:

- No special stages of heavy oil feedstock deasphalting and demetallization (asphaltenes, nickel and vanadium in the processing of the mineral deposit on the slate, and with the liquid products derived from the reactor);

- possibility of thermal cracking without hydrogen, and heat without using expensive hydrocracking catalysts and at a relatively low pressure (3-5 MPa);

- significant desulfurization materials (40-50\%).

All this reduces the capital and operating costs for processing of heavy crude oil into motor distillate fraction.

Depending on the field of oil shale and its method of activation may be a preference production of gasoline, diesel or fuel oil.

Liquid products of thermal cracking and hydrocracking of tar shale thermal cracking of tar mixed with shale and brown coal, as well as allocations of them petrol and diesel fraction contains sulfur, oxygen and nitrogen compounds, unsaturated hydrocarbons, and for the diesel fraction is also characterized by a high content of aromatic hydrocarbons.

As an example [5], the characteristic of liquid products of thermal cracking of tar mixtures, coal, oil shale and tar with slate.
To obtain commercial motor fuels from gasoline and diesel fractures thermal cracking of the shale and crude oil mixture required to conduct hydrogenetic ennoblement these fractions to remove heteroatomic compounds and products of partial hydrogenation of aromatics diesel fraction. Residue of the thermal cracking with bp. above $370^{\circ} \mathrm{C}$ can be used as a component of energy fuels (sulfur content less than $1.5 \%$, the low content of nickel and vanadium and 2.2-2.6 4.7-6.2 kg/m, respectively) and as bitumen for road construction. The solid residue (mineral part of the slate and deposited on it «coke») can serve as filler in the manufacture of asphalt can be removed from a nickel and vanadium. Thus, the proposed process is virtually waste-free.

\section{References}

1 Уайтхерст Д.Д., Митчелл Т.О., Форкаши М. Ожижение угля: пер. с англ. // под ред. В.Г. Липовича. - М.: Химия, 1986. - С. 60.

2 Химические вещества из угля // под ред. Ю. Фальбе: пер. с нем. // под ред. И.В. Калечица. - М.: Химия, 1980. - 611 с.

3 Pomrehh H., Rodegast M. Untersuchungsmethoden zur charakterisierung von Kohlen. 1. Analysen von Kohlen and Aschen. - Berlin: Acad. Wiss. DDR, 1981. - 263 p.

4 Касаточкин В.И., Ларина Н.К. Строение и свойства природных углей. - М.: Недра, 1975. -159 c.

5 Аубакиров Е.А. Ожижение угля и получение моторных топлив, технических продуктов из угольных дистиллятов с применением каталитических гидрогенизационных процессов: док. дисс. - Алматы, 2007. - 257 с.

6 Kairbekov Z.K., Yemelyanova V.S., Myltykbaeva Z.K., Bayzhomartov B.B. The brown coal and combustible slate(s) thermocatalytic processing of the «kenderlyk» deposit // European Journal of Natural History. - 2012. - №5, - P. 17-18.

Ж.Қ. Қайырбеков, В.С. Емельянова, Б.Б. Байжомартов

Көмір мен сланцтарды термокаталитикалық өңдеу

Бұл мақалада көмірдің органикалық массасы (КОМ) термокаталитикалық өзгеріске ұшырауы туралы сұрақтар қарастырылған, катализатор қатысынсыз процесс радикалды механизм бойынша орындалатыны көрсетілген. Жиналған материалдар радикалдық қасиеттеріне қарай әртүрлі құрылымды және әртүрлі реакциялық қабылеттілігіне сәйкес түсіну мүмкіндігі мен КОМ айналуын көрсетеді. КОМ-ның термиялық айналу процестері функционалды топтың ыдырауымен жүретін, сутегі атомы үшін өзара таласқа түсетін, радикалдарды түзейтін 
деполимеризация ретінде қарастырылады. Катализатор процестің жолы мен жағдайларын өзгертуге мүмкіндік береді. Казіргі катализаторлар процестің қысымын 50 атм. дейін төмендете отырып, көмірдің биік дәрежеде айналуына мүмкіндік береді. Бір сәтте көмір мен сланцтарды, сланцтар мен мазутты, сланцтар мен гудронды айналдыру мысалдары көрсетілген.

Tүйін сөздер: жанғыш сланцтар, көмір, катализатор, термокаталитикалық өңдеу, ыдырау, сұйық өнімдер.

\section{Ж.К. Каирбеков, В.С. Емельянова, Б.Б. Байжомартов \\ Термокаталитическая переработка угля и сланцев}

В статье рассмотрены вопросы термокаталитического превращения органической массы угля (ОМУ), показано, что в отсутствие катализатора процесс осуществляется по радикальному процессу. Накопленный материал по свойствам радикалов различного строения и, соответственно, разной реакционной способности дает возможность понять и интерпретировать превращения ОМУ. Термические превращения ОМУ рассматриваются как своего рода деполимеризация, сопровождающаяся разложением функциональных групп с образованием радикалов, конкурирующих между собой за атом водорода. Катализатор позволяет изменить направление и условия процесса. Современные катализаторы позволяют понизить давление процесса до 50 атм., при высокой степени превращения угля. Рассмотрены примеры одновременного превращения угля и сланцев, сланцев и мазута, сланцев и гудрона.

Ключевые слова: горючие сланцы, уголь, катализатор, термокаталитическая переработка, деструкция, жидкие продукты. 